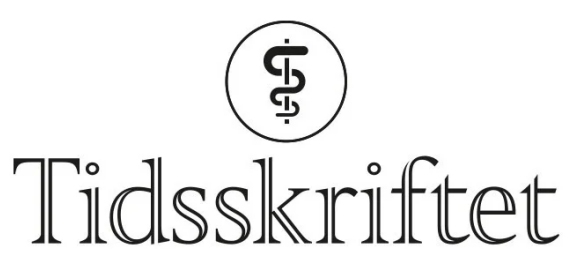

DEN NORSKE LEGEFORENING

\title{
Om hukommelse og hjernehelse til folket
}

ANMELDELSER

BJØRN LICHTWARCK

Overlege, Alderspsykiatrisk avdeling

Sykehuset Innlandet

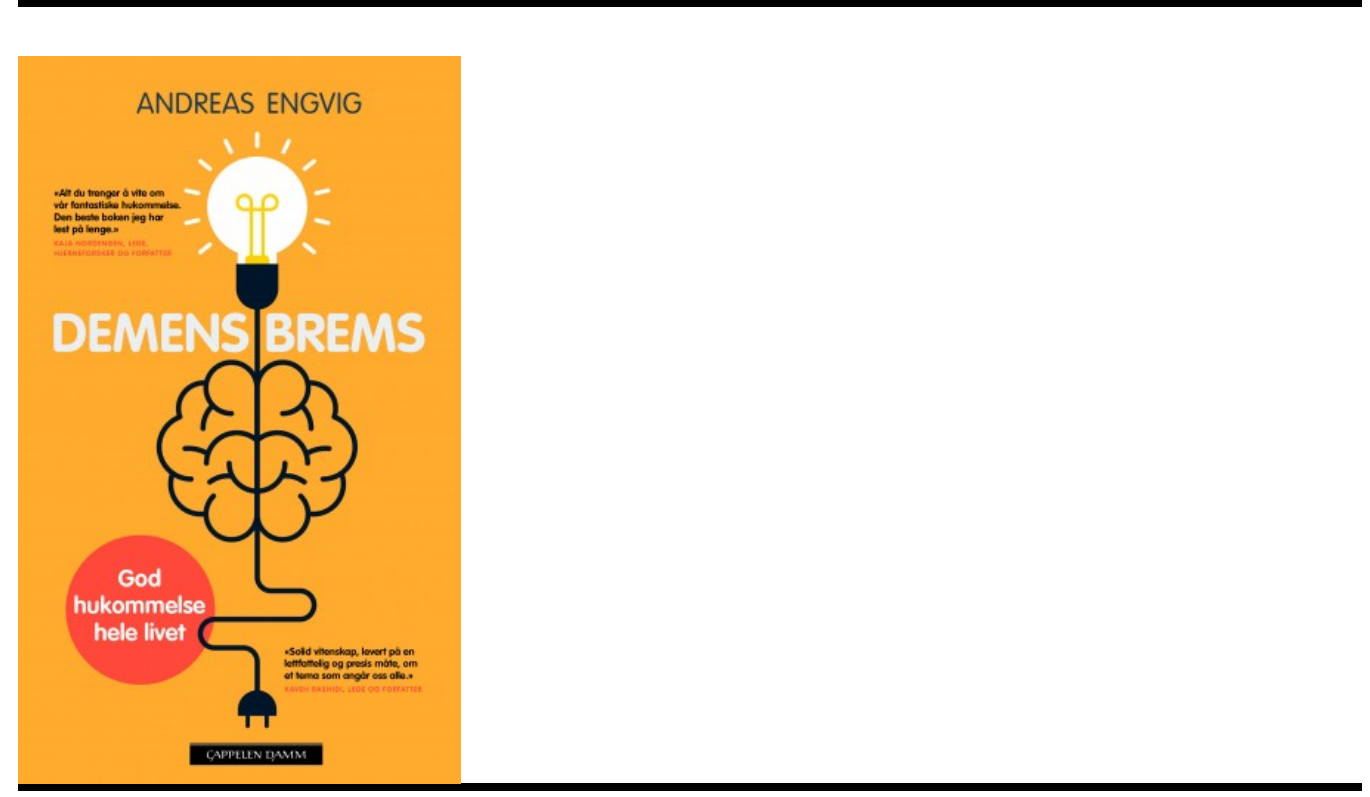

Andreas Engvig

Demensbrems

God hukommelse hele livet. 298 s, tab, ill. Oslo: Cappelen Damm, 2020. Pris NOK 378

ISBN 978-82-02-62931-1

Boka er et omfattende prosjekt der hovedmålsettingen er å formidle siste nytt om hva en kan gjøre selv for å få bedre hjernehelse og bevare hukommelsen gjennom livet. Forfatteren definerer innledningsvis målgruppen til å være de som er «midt i livet», dvs. mellom 30 og 60 år. Med andre ord er dette en variant av en selvhjelpsbok myntet på den vanlig mann og kvinne uten spesielle forhåndskunnskaper. 
I boka, som er inndelt i 14 kapitler, loser forfatteren leseren gjennom temaer som spenner fra nerveceller til hjernens anatomi, til hukommelse, demens og levevaner for god hukommelse.

Engvig bidrar med dette til å gjøre omfattende ny forskning tilgjengelig i et klart og enkelt språk, ofte med bruk av bilder fra hverdagslivet. Reseptorer i nerveterminaler i synapsene blir til fergeleier, og synapsene fungerer som et fergesamband. Det følger ofte gode illustrasjoner med forklaringene, selv om disse gjerne kunne vært i farger for å friske opp i en ellers nokså grå layout. Så å si samtlige påstander og råd har henvisninger til solid forskning, med en fullstendig referanseliste bakerst i boka. Det forklares at veien til bedre hjernehelse ikke består av noen enkle triks, men av mange sammensatte tiltak som forsterker hverandre. Dette gjør at denne selvhjelpsboken skiller seg ut i en jungel av like bøker som ofte er basert mer på forkynning og enkle løsninger enn på vitenskap. Det er prisverdig.

Samtidig er dette blitt en meget omfattende bok på hele 298 sider (utenom referansene), med nokså detaljerte beskrivelser som det krever en del av leseren for å forstå. Det blir også en del gjentagelser. Siden målgruppen er den vanlige mann og kvinne, kunne innholdet med fordel vært strammet opp og kortet ned.

Boken skiller seg også ut ved at den på slutten bringer inn et samfunnsperspektiv på forebygging. Engvig påpeker at ulikhet i økonomi og utdannelse påvirker våre muligheter til å dra nytte av helseopplysning og til å gjennomføre endringer i eget liv. Forfatteren foreslår at samfunnet må sette inn hjernehelsetiltak som særlig treffer de som trenger det mest. Her kunne det vært på sin plass å si at det mest effektive tiltaket for bedre helse, inkludert hjernehelse, er utjevning av denne ulikheten på arenaer utenfor helsevesenet.

Boken anbefales for den alminnelige leseren som er litt over gjennomsnittet interessert $\mathrm{i}$ hjernehelse, demens og hukommelse.

Publisert: 28. september 2020. Tidsskr Nor Legeforen. DOI: 10.4045/tidsskr.20.0597

(C) Tidsskrift for Den norske legeforening 2023. Lastet ned fra tidsskriftet.no 26. april 2023. 